\title{
Analysis of Food and Beverage Sales and Consumer Profile of Railway Restaurants
}

\author{
Edhi Susetyo Sepudjo', Mukhamad Najib², Kirbrandoko ${ }^{3}$ \\ ${ }^{1,2,3}$ Business School, Institut Pertanian Bogor, J1. Raya Pajajaran, Bogor 16151 \\ Corresponding Author: Edhi Susetyo Sepudjo
}

\begin{abstract}
This research was motivated by the fact that the number of sales of food and beverages in railroad restaurants is still very small and can still be increased considering all the potentials of the company. It takes the right strategy in order to increase sales at railroad restaurants. However, before formulating this strategy, it is necessary to study the factors that influence sales in railroad restaurants. This study aims to analyze the variables of the schedule, duration, and class of travel on sales at the Kereta Api Restaurant (RESKA). The method used to process the data is Structural Equation Modeling (SEM)-PLS version 3.0. The results showed that the train travel schedule had a significant and positive effect on sales at the Railway Restaurant. While other variables have no significant effect. Therefore, to improve the sales performance of railroad restaurants, programs and product innovations related to train travel schedules are needed, so as to improve sales performance, both sales of heavy food, snacks and drinks at Railway Restaurants.
\end{abstract}

Keywords: train journey duration, train travel class, train journey length, train restaurant sales, SEM.

\section{PRELIMINARY}

Traveling by train has become part of the culture of the Indonesian people, this can be seen from the use of trains in the annual Lebaran homecoming routine. The great interest of the Indonesian people in using trains to travel is a separate business opportunity that can be utilized in marketing various products that passengers need while traveling.
Based on data from the Central Statistics Agency, the number of train passengers in Indonesia from year to year continues to increase. One of the reasons is the increasing quality of service, both longdistance trains and Jabodetabek trains. This is in line with research conducted by Maelani (2018). The application of minimum service standards has a significant effect on the loyalty of train passengers.

PT Kereta Api Indonesia (PT KAI) as one of the train operators in Indonesia continues to strive to improve services to passengers. One of them is providing a restaurant on the train journey. PT KAI established PT Reska Multi Usaha (PT RMU) as a subsidiary in charge of managing train restaurants and other rail travel supporting businesses. PT RMU's total revenue from the sale of food and beverages at train restaurants is still very small when compared to the number of nonJabodetabek train passengers. Therefore we need the right strategy in order to increase sales at railroad restaurants. However, before formulating this strategy, a research is needed on the factors that influence sales at railroad restaurants.

Table 1 Railway Restaurant Sales Revenue Data

\begin{tabular}{|l|l|}
\hline Year & Amount (Rupiah) \\
\hline 2017 & 206109541415 \\
\hline 2018 & 286525568126 \\
\hline
\end{tabular}

Based on the data above, when compared to sales revenue from train restaurants with the number of non Jabodetabek train passengers in 2017 and 
2018, each passenger only shopped at train restaurants for IDR 2662 and IDR 3358. This number is quite small, this is can be compared with the daily standard for domestic official travel for civil servants which refers to the input fee standard for 2020 (PP number 78/PMK.02/2019 concerning Standard Input Fee for Fiscal Year 2020). The average daily cost for the island of Java reaches IDR 421667.

Table 2 Comparison of Business Travel Costs to Passenger Expenditure

\begin{tabular}{|c|c|c|c|c|c|}
\hline \multirow[t]{2}{*}{ Province } & \multirow{2}{*}{$\begin{array}{l}\text { Daily expenses for business } \\
\text { trips (Rupiah) }\end{array}$} & \multicolumn{4}{|c|}{ Restoration Sales / Number of Passengers } \\
\hline & & $\begin{array}{l}\text { 2017 Passenger } \\
\text { Shopping } \\
\text { (Rupiah) }\end{array}$ & $\begin{array}{l}\text { \% Against } \\
\text { Average }\end{array}$ & $\begin{array}{l}\text { 2018 Passenger } \\
\text { Shopping } \\
\text { (Rupiah) }\end{array}$ & $\begin{array}{l}\text { \% Against } \\
\text { Average }\end{array}$ \\
\hline Banten & 370000 & \multirow{7}{*}{2662} & \multirow{7}{*}{$0.63 \%$} & \multirow{7}{*}{3358} & \multirow{7}{*}{$0.80 \%$} \\
\hline West Java & 430000 & & & & \\
\hline DKI Jakarta & 530000 & & & & \\
\hline Central Java & 370000 & & & & \\
\hline In Yogyakarta & 420000 & & & & \\
\hline East Java & 410000 & & & & \\
\hline Average & 421667 & & & & \\
\hline
\end{tabular}

Based on the data above, it is known that the number of sales of food and beverages at railroad restaurants is still very small and can still be increased. The right strategy is needed in order to increase sales at railroad restaurants. However, before formulating this strategy, a research is needed on the factors that influence sales at railroad restaurants.

The role of the schedule, duration and class of travel has always been a special concern by the management of PT Reska Multi Usaha (PT RMU) in carrying out its sales strategy, assuming that these three factors greatly affect the level of food and beverage sales on the train. However, this assumption is still a hypothesis that has not been supported by valid research. Therefore, research is needed that analyzes the factors that influence the sales of food and beverages in train restaurants.

This study aims to: 1) Knowing the profile, needs and desires of train passengers, especially those related to eating and drinking on a train journey; and 2) Analyzing the effect of the schedule, duration, and class of travel on sales of heavy meals, snacks, and beverages at train restaurants.

\section{Consumer behavior}

Consumer Behavior is the investigation of individuals, groups, or associations with the procedures they use to select, secure, and dispose of products, services, experiences, or ideas to meet consumer needs. There are two types of consumer behavior, namely consumeroriented cognitive and behavioral experience. Consumers with cognitive behavior are logical and rational consumers, while those with behavioral experience are more motivated to buy products (Karam, 2015).

The research of Gueguen et al. (2006) explained that the smell of a restaurant can affect consumer behavior, including the length of time spent in the restaurant and the amount of money spent. A comfortable aroma is very important to make consumers feel at home in a restaurant, so that it has the opportunity to increase restaurant sales.

The behavior of consumers associating the purchase of food or beverages is largely based on their value framework. The consumer value framework consists of brand image, class association, brand, price and awareness of the entire product relative to others (Haemoon, 2000). Research conducted by Farris et al. (2010) describe that purchasing decisions are made by consumers. Cognitively influenced significantly by brand image and awareness among target products. Research also shows that products that have a high brand image and higher awareness among consumers are more likely to be purchased by consumers (Hoyer, 1990). Therefore, specifically to encourage repeat buying behavior in 
consumers, brand awareness can be considered as an important aspect (Macdonald, 2000).

Arslan and Altuna (2010) define brand image as positive and negative feelings about the brand to the customer's brain unexpectedly or when they recall their memories. They are of the view that there are three aspects of brand image that make up the overall brand image including positivity, strength, and distinctiveness. Lee et al. (2011) describes brand image as a reflection of the general personality and beliefs about a particular brand by keeping in mind its uniqueness that makes it different from other brands.

\section{Buying decision}

Consumer decision making can be defined as the mental orientation that characterizes the consumer's approach to making choices (Lysonski et al., 1996). This approach uses cognitive and affective orientations in the decision-making process. Food and beverage packaging has the potential to influence consumer purchasing decisions, this packaging is divided into two categories, including visual and informational elements. Visual elements consist of graphics and the size or shape of the packaging, and are more related to the affective side of decision making. Information elements relate to the information provided and the technologies used in the package, and are more likely to deal with the cognitive side of decisions (Silayoi, 2004).

Graphics are visual elements including layout, color combinations, typography, and product photography, all of which create an image. This graph has a great impact on marketing communications, image building, and consumer decision making (Grossman and Wisenblit, 1999). The size and shape of the packaging also influence consumer judgments and decisions. If the difference in volume is not too large, consumers will focus more on assessing the shape of the packaging (Raghubir and Krishna, 1999). Different packaging sizes lead to more economical factors. If two foods with different package sizes are sold at the same price, consumers are more likely to buy the larger package size (Prendergast and Marr, 1997).

There are times when consumer behavior towards food or drink is less influenced by image problems or visual response so that consumers need more information in some cases. The information written on the package can help consumers in making decisions carefully because they consider the characteristics of the product. However, packaging information can cause confusion by conveying too much information or misleading and inaccurate information (Kupiec and Revell, 2001). Mitchell and Papavassiliou (1999) suggest that one way consumers reduce confusion from information overload is to narrow their choices. Reducing alternative choices will reduce consumer confusion due to choice and information overload. This strategy can be applied by more experienced consumers, because they have the potential to see brands with fewer alternatives. In other words, experience makes consumers perceptive and selective limits the scope of their search (Hausman, 2000).

\section{Research Model Concepts and Hypotheses}

\begin{tabular}{|l|l|l|}
\hline Hypothesis 1 & $:$ & Train Travel Schedule has a positive and significant effect on Sales at train restaurants \\
\hline Hypothesis 2 & $:$ & The duration of the train journey has a positive and significant effect on sales at train restaurants \\
\hline Hypothesis 3 & $:$ & Train Travel Class has a positive and significant effect on Sales at train restaurants \\
\hline
\end{tabular}

\section{METHOD}

This research was conducted on PT Reska Multi Usaha (PT RMU) and people who have traveled by non-Jabodetabek trains in the period from January to
February 2020. As for the role of travel schedules, duration and class of trains on sales at train restaurants, using sales data for September 2019. 
The data used in this study include primary data and secondary data. Primary data was obtained from filling out questionnaires that had been tested for reliability to a number of respondents with a total of 110 respondents.

In this study, descriptive analysis was used to analyze the characteristics of train restaurant consumers. Processing and analyzing data for this study used Structural Equation Modeling (SEM) - Partial Least Square (PLS). Structural Equation Modeling (SEM) is used to calculate the effects that arise from the relationship between variables that are processed based on the results of data collection by respondents. The selection for data processing using SEM-PLS is expected to show the effect of the latent variables being tested, to find out whether or not there is and the size of the influence between variables (Latan 2013). PLS-SEM analysis consists of two submodels, namely the measurement model or often called the external model (outer model) and the structural model or often called the inner model (inner model).

\section{RESULTS}

\section{Research Object Profile}

PT Reska Multi Usaha (PT RMU) is a subsidiary of PT Kereta Api Indonesia (PT KAI) which focuses on developing business derivatives from PT KAI such as train restaurant management, station cleaning and cleaning services on train journeys, parking, restaurants, catering. and Cafe, Management of minimarkets and other railway supporting businesses.

\section{Travel itinerary}

The departure schedule in this study is classified into three parts, namely morning, afternoon and evening. The morning departure schedule is trains departing within the time range of $04.01-$ 10.00 , the afternoon departure schedule is the train departing within the time range 10.01 - 18.00 and the evening departure schedule is those departing within the time range $18.01-04.00$.

\section{Travel Class}

In the study, what is meant by travel class is the classification of train travel classes per train series, the classification is divided into 3 classes, namely:

1. Executive class, namely a series of trains which in one series consist of executive class carriages or arranged with the above class carriages (priority and sleeper).

2. Economy class, which is a series of trains which in one series consist of business class carriages and lower class cars (economy, premium economy and PSO economy)

3. Mixed class, which is a series of trains which in one series consist of at least two classes of carriages, one of which is an executive class car and above (executive, priority and sleeper). Examples of trains are Brantas, Argo Cheribon, Sancaka.

\section{Travel Duration}

The duration of the trip in this study is divided into 3 , namely:

1. Short travel duration, namely the duration of the train journey with a maximum travel time of 4 hours $(0-4$ hours);

2. Medium travel duration, namely train travel with a travel time of between 4 hours and 1 minute to a maximum of 8 hours; and

3. The duration of the long journey, namely the train journey with a long journey of more than 8 hours.

\section{Characteristics of Respondents}

The results of a survey of 110 respondents who non-Jabodetabek longdistance train users, obtained Characteristics of the respondents, which are presented in Table 3, include the characteristics of gender, age, marital status, total income, purpose of using the train, and traveling with whom. 
Table 3 Characteristics of Respondents

\begin{tabular}{|c|c|c|c|c|}
\hline \multirow{3}{*}{$\begin{array}{l}\text { CHARACTERISTICS } \\
\text { GENDER }\end{array}$} & \multicolumn{4}{|l|}{ DATA } \\
\hline & Male & Woman & & \\
\hline & $56.4 \%$ & $43.6 \%$ & & \\
\hline \multirow[t]{2}{*}{ AGE RANGE } & $20-30$ & $31-40$ & $41-50$ & $>50$ \\
\hline & $29.1 \%$ & $44.5 \%$ & $16.4 \%$ & $10.0 \%$ \\
\hline \multirow[t]{2}{*}{ MARITAL STATUS } & bachelor & Marry & Widower widow & \\
\hline & $23.6 \%$ & $73.6 \%$ & $2.7 \%$ & \\
\hline \multirow[t]{2}{*}{ TOTAL INCOME/MONTH } & $\begin{array}{l}\text { Not enough } \\
<4 \text { million }\end{array}$ & $\begin{array}{l}\text { Between } \\
4-10 \text { million }\end{array}$ & $\begin{array}{l}\text { More } \\
<10 \text { million }\end{array}$ & \\
\hline & $16.4 \%$ & $46.4 \%$ & $37.3 \%$ & \\
\hline \multirow[t]{2}{*}{ PURPOSE OF USING KA } & Family needs & Business/office/office duties & Holiday & Go home/go to work \\
\hline & $42.7 \%$ & $23.6 \%$ & $20.9 \%$ & $12.7 \%$ \\
\hline \multirow[t]{2}{*}{ TRAVEL WITH } & Own & Family+ & Together & $>2$ coworkers \\
\hline & $40 \%$ & $25.5 \%$ & $23.6 \%$ & $10.9 \%$ \\
\hline
\end{tabular}

Respondent data was obtained from online questionnaires in the Jabotabek area from August to October 2020. All respondents were customers who had used non-Jabotabek long-distance rail transportation services for the period January - February 2020. In table 3, it is known that of all respondents The sample is non-Jabodetabek long-distance train users, totaling 110 respondents, with male sex as many as 62 respondents $(56.4 \%)$ and female sex as many as 48 respondents $(43.6 \%)$.

Furthermore, respondents' data regarding age characteristics. all respondents who became the object of the sample of non-Jabodetabek long-distance train service users amounted to 110 respondents with the following composition, namely: those aged less than 20-30 years were 32 respondents $(29.1 \%)$, ages between $30-40$ years were 49 people $(44.5 \%), 18$ people aged between $40-50$ years $(16.4 \%)$, and 11 people over 50 years old $(10 \%)$. These results illustrate that the largest segment of out-of-town trains are passengers aged 20-30 years and 30-40 years.

The next respondent's characteristics are passengers based on marital status. Table 4 shows that as many as 81 respondents or $73.6 \%$ are married, 26 respondents or $23.6 \%$ of respondents are unmarried, and 3 respondents or $2.7 \%$ have widowed/widow status.

Next on the characteristics of respondents' income per month. According to Soekarwati (2003), income will affect the number of goods consumed, it is often found that with an increase in a person's income, the goods consumed will also increase. In the table above, the characteristics of respondents based on income are 18 respondents $(16.4 \%)$ earning $<\mathrm{Rp} 4$ million per month, 51 respondents (46.4\%) earning $\mathrm{Rp} 4$ million - Rp 10 million per month, and 41 respondents (37.3\%) income of > IDR 10 per month

Also in the tableexplained that there are 47 respondents $(42.7 \%)$ using trains for family purposes, 26 respondents $(23.6 \%)$ using trains for business/service/office tasks, 23 respondents $(20.9 \%)$ using trains for vacations, and 14 respondents respondents $(12.7 \%)$ use the train to go home/go to work at the end of the week/beginning of the week.

Finally, it aims to find out how many people travel by train together with the respondent. From 110 respondents, it was found that 44 respondents $(40 \%)$ traveled alone, 28 respondents $(25.5 \%)$ traveled with more than two family members, 26 respondents $(23.6 \%)$ traveled with one coworker/friend/family, and 12 respondents (10.9 \%) traveling with more than two coworkers/friends.

\section{Analysis Structural Equation Model (SEM) - PLS}

Structural Equation Modeling (SEM) was used to perform path analysis (path) with latent variables. In the Research Model, the latent variables used in this study are the departure schedule, duration and class of train travel. Structural model testing's in PLS is carried out using SmartPLS software version 2. The steps that must be carried out in Partial Least Square 
(PLS) include: 1) Structural Model Schematic (inner model) and 2) Measurement model (Outer Model); 3). Model evaluation Construct path diagrams; 4). Hypothesis test.

\section{Validity and Reliability (Outer Model) a) Convergent validity}

According to Hair et al. (2014), an indicator is declared valid if it has an outer loading value of more than 0.70 . The outer loadings are presented in Table 2. The convergent validity of the measurement model with the index reflection model was assessed on the basis of the correlation between item scores and construct scores calculated by PLS. The outer loadings obtained on each indicator are more than 0.70. These results indicate that the indicators are valid, in other words, all indicators have a correlation with their respective structures or variables.

Table 4 Outer Loadings

\begin{tabular}{|l|l|l|l|l|}
\hline & TRIP DURATION & TRAVEL ITINERARY & TRAVEL CLASS & SALES IN THE RESTAURANT \\
\hline DRS1 & 0.977 & & & \\
\hline DRS2 & 0.977 & & & \\
\hline DRS3 & 0.952 & & & \\
\hline JDW1 & & 0.968 & & \\
\hline JDW2 & & 0.943 & & \\
\hline JDW3 & 0.975 & & \\
\hline KLS1 & & & 0.957 & \\
\hline KLS2 & & & 0.970 & \\
\hline KLS3 & & & 0.953 & \\
\hline PJL1 & & & & 0.921 \\
\hline PJL2 & & & & 0.952 \\
\hline PJL3 & & & \\
\hline
\end{tabular}

\section{b) Discriminant validity}

According to Hair et al. (2014), discriminant validity is carried out with the aim of describing the extent to which indicators reflect latent variables. Discriminant validity is presented in Table 3 and cross loadings in Table 4. Discriminant validity is declared good, if the value of each latent variable is greater than the value of the other variables, and the value of cross loadings must be greater than 0.70 and the loading value of each indicator on the latent variable must be greater than the loading value of the other variables. In Table 3, the discriminant validity value of each latent variable is greater than that of the other variables. The value of cross loadings obtained in Table 4 is more than 0.70 . Other than that, the loading value of each indicator on the latent variable is greater than the loading value of the other variables. These results indicate that the level of discriminant validity is good.

Table 5 Discriminant Validity

\begin{tabular}{|l|l|l|l|l|}
\hline & $\begin{array}{l}\text { TRIP } \\
\text { DURATION }\end{array}$ & $\begin{array}{l}\text { TRAVEL } \\
\text { ITINERARY }\end{array}$ & TRAVEL CLASS & $\begin{array}{l}\text { SALES IN THE } \\
\text { RESTAURANT }\end{array}$ \\
\hline TRIP DURATION & 0.969 & & & \\
\hline TRAVEL ITINERARY & 0.964 & 0.962 & & \\
\hline TRAVEL CLASS & 0.960 & 0.944 & 0.960 & \\
\hline SALES IN THE RESTAURANT & 0.942 & 0.957 & 0.946 & 0.943 \\
\hline
\end{tabular}

Table 6 Cross Loadings

\begin{tabular}{|l|l|l|l|l|}
\hline & TRIP DURATION & TRAVEL ITINERARY & TRAVEL CLASS & SALES IN THE RESTAURANT \\
\hline DRS1 & 0.977 & 0.951 & 0.969 & 0.916 \\
\hline DRS2 & 0.977 & 0.964 & 0.914 & 0.939 \\
\hline DRS3 & 0.952 & 0.884 & 0.908 & 0.881 \\
\hline JDW1 & 0.931 & 0.968 & 0.917 & 0.912 \\
\hline JDW2 & 0.895 & 0.943 & 0.903 & 0.913 \\
\hline JDW3 & 0.955 & 0.975 & 0.906 & 0.938 \\
\hline KLS1 & 0.957 & 0.905 & 0.957 & 0.901 \\
\hline KLS2 & 0.927 & 0.916 & 0.970 & 0.889 \\
\hline KLS3 & 0.881 & 0.899 & 0.953 & 0.922 \\
\hline PJL1 & 0.807 & 0.864 & 0.807 & 0.921 \\
\hline PJL2 & 0.902 & 0.921 & 0.932 & 0.952 \\
\hline PJL3 & 0.951 & 0.922 & 0.931 & 0.957 \\
\hline
\end{tabular}


c) Average Variance Extracted (AVE). AVE value's

Calculation of the value of Average Variance Extracted (AVE) is carried out to describe the magnitude of the variance or diversity of variables in the latent construct
(Yamin and Kurniawan, 2011). Convergent validity if the AVE value is more than 0.50 . In Table 5, the AVE value of each indicator is more than 0.50 . Based on these results, it can be concluded that all variables in this study are valid.

Table 7 Construct Reliability and Validity

\begin{tabular}{|l|l|l|l|l|}
\hline & Cronbach's Alpha & rho_A & Composite Reliability & Average Variance Extracted (AVE) \\
\hline DURATION & 0.967 & 0.968 & 0.979 & 0.939 \\
\hline TIMETABLE & 0.960 & 0.960 & 0.974 & 0.926 \\
\hline CLASS & 0.957 & 0.957 & 0.972 & 0.921 \\
\hline RESTAURANT SALES & 0.938 & 0.941 & 0.960 & 0.890 \\
\hline
\end{tabular}

\section{d) Unidimensionality}

\section{Composite Reliability and Cronbach} Alpha.

According to Yamin and Kurniawan (2011), a variable is said to be reliable if it has a composite reliability and Cronbach alpha value of more than 0.70. Based on
Table's 5, all variables have Cronbach alpha and composite reliability values of more than 0.70 , so it can be concluded that all variables used are reliable.

The measurement model tested can be seen in Figure 2:

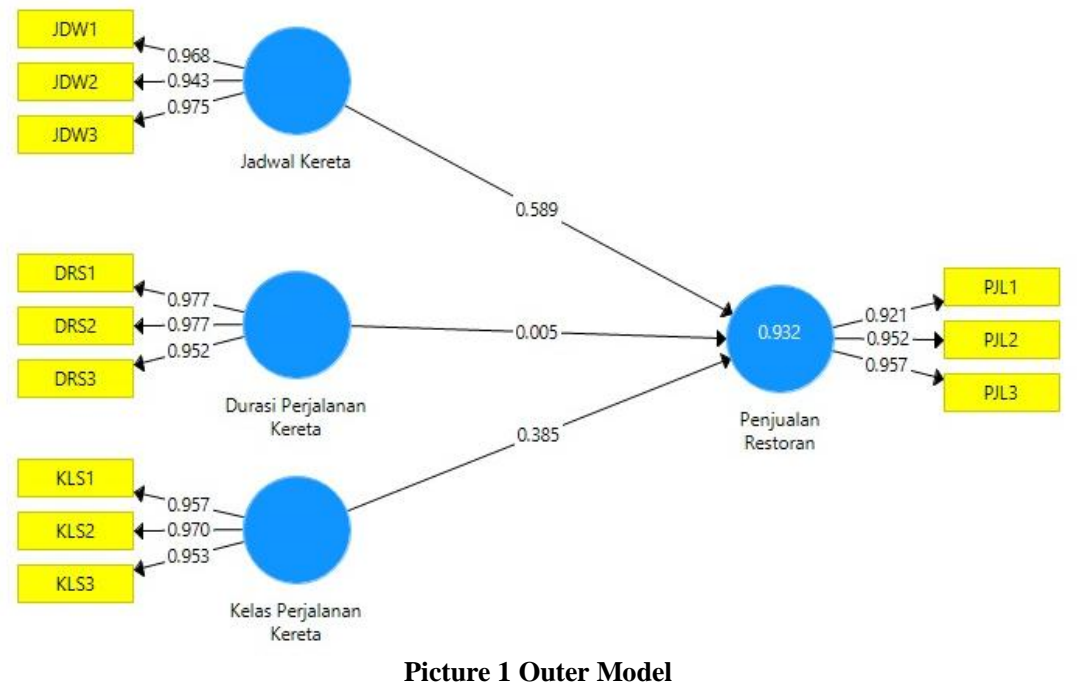

The Effect of Variables on the Model (Inner models)

In this evaluation, measurement by looking at R2, Q2 and GoF.

\section{a) R-square.}

According to Hair et al. (2014), the value of R2 (R-square) describes a measure of the model's prediction accuracy. The dependent variable in this study is sales at railroad restaurants. The value of $\mathrm{R} 2$ (Rsquare) in this study can be seen in Table 6 . The R-square value obtained is 0.932 . This means that train travel schedules affect sales at train restaurants by $93.2 \%$.

Table 8 R Square
\begin{tabular}{|l|l|l|}
\hline & $\boldsymbol{R}$ Square & $\boldsymbol{R}$ Square Adjusted \\
\hline RESTAURANT SALES & 0.932 & 0.919 \\
\hline
\end{tabular}

\section{b) Path Coefficients}

According to Yamin and Kurniawan (2011), the path coefficient is useful for seeing the significance of the relationship between latent variables. A path is said to have a significant effect if it has a T-statistic value greater than the T-table with a T-table value of 1.96 (at 5\% significance level) and $\mathrm{p}$-values less than 0.05 . The original sample value describes the relationship between the latent variables that is positive or negative. The results of hypothesis testing through 
path coefficients can be seen in Table 7 . Based on table $7, \mathrm{H} 2$ and $\mathrm{H} 3$ are rejected while $\mathrm{H} 1$ is accepted, because the Tstatistics are less than T-table (1.96) and P- values are more than 0.05 . So, it can be concluded that the train travel schedule has a positive and significant effect on sales at train restaurants.

Table 9 Path Coefficients

\begin{tabular}{|l|l|l|l|l|l|}
\hline & $\begin{array}{l}\text { Original Sample } \\
(\mathbf{O})\end{array}$ & $\begin{array}{l}\text { Sample Mean } \\
(\mathbf{M})\end{array}$ & $\begin{array}{l}\text { Standard Deviation } \\
(\text { STDEV })\end{array}$ & $\begin{array}{l}\text { T Statistics } \\
(\mid \mathbf{O} / \text { STDEV })\end{array}$ & $\begin{array}{l}\text { P } \\
\text { Values }\end{array}$ \\
\hline $\begin{array}{l}\text { TRAIN TRAVEL } \\
\text { DURATION }\end{array}$ & 0.005 & -0.106 & 0.369 & 0.014 & 0.989 \\
\hline TRAIN SCHEDULE & 0.589 & 0.606 & 0.283 & 2.076 & 0.038 \\
\hline TRAIN TRAVEL CLASS & 0.385 & 0.478 & 0.381 & 1.009 & 0.313 \\
\hline
\end{tabular}

c) Effect size (f-square). Performed to determine the inverse of the model.

The recommended effect sizes $\mathrm{f} 2$ in a study are $0.02,0.15$, and 0.35 with exogenous latent variables having small, medium and large effects on the structural level. Table 8 shows the effect of train travel schedules on sales at large train restaurants because the $\mathrm{f} 2$ is 0.339 , and the effect of train travel class on sales at medium train restaurants because the $\mathrm{f} 2$ is 0.160 , while the duration of train travel does not affect sales in train restaurant.

Table 10 f Square
\begin{tabular}{|l|l|}
\hline \multicolumn{1}{|c|}{} & RESTAURANT SALES \\
\hline TRAIN TRIP DURATION & 0.000 \\
\hline TRAIN SCHEDULE & 0.339 \\
\hline TRAIN TRAVEL CLASS & 0.160 \\
\hline
\end{tabular}

The structural model of this research can be seen in Figure 3.

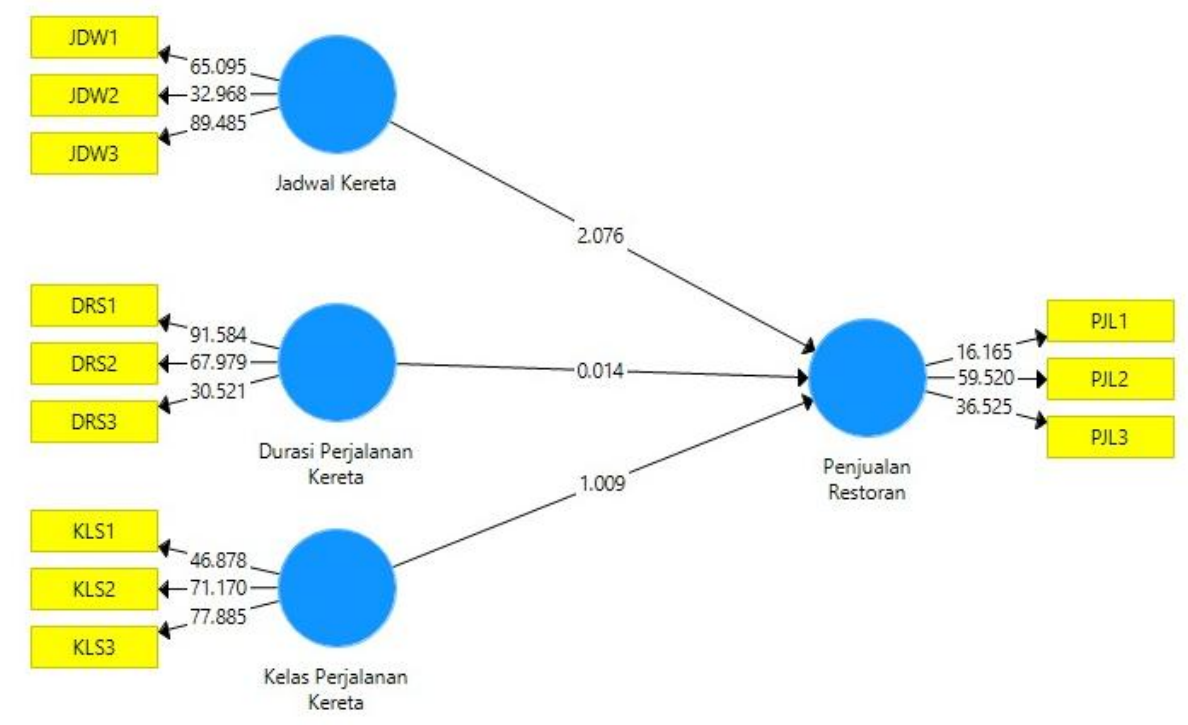

Figure 3 Inner Model

\section{Hypothesis test}

Hypothesis testing is carried out to answer the research objectives. The answers to this hypothesis are obtained in Table 7. The results of the hypothesis testing are as follows.

H1: Train Travel Schedule has a positive and significant effect on sales at train restaurants.

Based on the Path Coefficients test in Table 7, the p-value is 0.038 (p-value <
$0.05)$ and the t-statistic value is $2.076(\mathrm{t}-$ statistics > 1.96), so H0 is rejected. This shows that train travel schedules have a positive and significant effect on sales at train restaurants.

$\mathrm{H} 2$ : The duration of the train journey has a positive and significant effect on sales at train restaurants.

Based on the Path Coefficients test in Table 7, the p-value is 0.989 (p-value > $0.05)$ and the $t$-statistic value is $0.014(\mathrm{t}-$ 
statistic < 1.96), so H0 is accepted. This shows that the duration of the train journey has no effect on sales at train restaurants.

H3: Train Travel Class has a positive and significant effect on sales at train restaurants.

Based on the Path Coefficients test in Table 7, the p-value is 0.313 ( $\mathrm{p}$-value > $0.05)$ and the t-statistic value is $1.009(\mathrm{t}-$ statistic < 1.96), so H0 is accepted. This shows that the class of train travel has no effect on sales at train restaurants.

\section{Managerial Implications}

Based on the results of the study, it is known that train travel schedules have a positive and significant effect on sales at train restaurants. The managerial implications that can be applied to increase sales at railroad restaurants refer to the Blue Ocean theory. That is a strategy that creates a new market space, which is formed by identifying groups of consumers who have not been served and then providing them with an attractive new product or value (Lasher 2004). This is in line with the market conditions of the unique railroad restaurant, namely the passengers will remain in the train carriage during the journey. Thus creating a group of consumers who must be served in meeting the needs during the trip.

\section{CONCLUSION AND}

\section{RECOMMENDATIONS}

\section{Conclusion}

1. Consumer characteristics of nonJabotabek train users are male and female, aged 20 to 40 years, married status, with income between Rp. 4 million to Rp. 10 million jobs, and the majority use the train for family purposes.

2. Train Travel Schedule has a positive and significant effect on sales at Railway Restaurants, so it can be concluded that the increase in train restaurant sales is significantly influenced by Train Travel Schedules.

\section{Suggestion}

1. The results of the study recommend to PT Reska Multi Usaha to innovate in promoting and educating the train user community about the culinary diversity of the archipelago and the ease of getting these foods during train journeys. The composition of train users, which are mostly dominated by productive age, is the capital to carry out promotions in a contemporary and sustainable manner technology updates.

2. From the results of this study, further research can be carried out regarding the choice of the right strategy in promoting the sale of food and beverages at restaurants in general or train restaurants in particular.

\section{Acknowledgement: None}

\section{Conflict of Interest: None}

\section{Source of Funding: None}

\section{REFERENCES}

1. Arslan, FM, Altuna, OK (2010): The Effect of Brand Extensions on Product Brand Image, Journal of Product and Brand Management, 19, 170-180.

2. Farris, Paul WW, Neil TB, Phillip EP, and David, JR (2010): Marketing Metrics: The Definitive Guide to Measuring Marketing Performance, Upper Saddle River, New Jersey: Pearson Education.

3. Grossman, RP and Wisenblit, JZ (1999): What We Know about Consumers Color Choices, Journal of Marketing Practice, Applied Marketing Science, 5, 78-88.

4. Gueguen, N. and Petr, C. (2006). Odors and consumer behavior in a restaurant, International Journal of Hospitality Management, 25, 335-339.

5. Hair, JF, Sarstedt, M., Hopkins, L., and Kuppelwieser, VG (2014): Partial Least Squares Structural Equation Modeling (PLS-SEM) An Emerging Tool in Business Research, European Business Review, 26, 106-121.

6. Haemoon, O. (2000): The Effect of Brand Class, Brand Awareness, and Price on Customer Value and Behavioral Intentions, 
Journal of Hospitality and Tourism Research, 24, 136-162.

7. Hausman, A. (2000): A Multi-method Investigation of Consumer Motivations in Impulse Buying Behavior, Journal of Consumer Marketing, 17, 403-19.

8. Hoyer, WD, and Steven PB (1990): Effects of Brand Awareness on Choice for a Common, Repeat-Purchase Product, Journal of Consumer Research, 17, 141-148.

9. Karam, A., K. (2015): An Analysis Study of Improving Brand Awareness and Its Impact on Consumer Behavior Via Media in North Cyprus (A Case Study of Fast Food Restaurants), International Journal of Business and Social Science, 6, 66 -80.

10. Kupiec, B. and Revell, B. (2001): Measuring consumer quality judgments, British Food Journal, 103, 7-22.

11. Lasher RL. 2004. Blue Ocean Strategy. New York: CSC World.

12. Lee, HM, Lee, CC, and Wu, C, C. (2011). Brand Image Strategy Affects Brand Equity after M\&A, European Journal of Marketing, 45, 1091-1111.

13. Macdonald, Emma, K., and Byron MS, (2000): Brand Awareness Effects on Consumer Decision Making for a Common, Repeat Purchase Product: A Replication, Journal of Business Research, 48, 5-15.

14. Maelani S, Endang S. 2018. Increasing passenger loyalty through minimum service standards on the Pangrango Train on the Bogor - Sukabumi Line. Visionida Journal. 4(2): 38-53.

15. Mitchell, VW and Papavassiliou, V. (1999): Marketing Causes and Implications Of
Consumer Confusion, Journal of Product and Brand Management, 8, 319-39.

16. Prendergast, PG and Marr, NE (1997): Generic Products: Who Buys Them and How Do They Perform Relative to Each Other?, European Journal of Marketing, 31, 94-109.

17. Raghubir, P. and Krishna, A. (1999): Vital Dimensions in Volume Perception. Can the Eye Fool The Stomach?, Journal of Marketing Research, 36, 313-26.

18. Silayoi, P. and Speece, M. (2004): Packaging and Purchase Decisions: An Exploratory Study on The Impact of Involvement Level and Time Pressure, British Food Journal, 106, 607-628.

19. Latan H. 2013. Structural Equation Model Theory and Implementation. Bandung (ID): CV Alfabeta

20. Lysonski, S., Durvasula, S. and Zotos, Y. (1996): Consumer Decision-making Styles: a multi-country investigation, European Journal of Marketing, 30, 10-21.

21. Yamin, S., Kurniawan, H., 2011. New Generation Processing Research Data with Partial Least Square Path Modeling: Applications with XLSTAST, SmartPLS, and Visual PLS Software. Salmeba Infotek, Jakarta.

How to cite this article: Sepudjo ES, Najib M, Kirbrandoko. Analysis of food and beverage sales and consumer profile of railway restaurants. International Journal of Research and Review. 2021; 8(10): 402-411. DOI: https://doi.org/10.52403/ijrr.20211054 